\title{
Cervical Rib Which Resembles Original Thoracic Rib Presenting with Thoracic Outlet Syndrome (TOS): Literature Review with a Case Report
}

\author{
Costilla Cervical que se Asemeja a una Costilla Torácica Presentándose con Síndrome \\ de Salida Torácica (SST): Revisión de la Literatura a partir de Un Caso Clínico
}

\author{
Vaner Köksal
}

\begin{abstract}
KÖKSAL, V. Cervical rib which resembles original thoracic rib presenting with thoracic outlet syndrome (TOS): Literature review with a case report. Int. J. Morphol., 37(4):1522-1526, 2019.

SUMMARY: The cervical rib (CR) is a rare skeletal anomaly, which generally articulated with the transverse process of the 7th cervical vertebra, and commonly lead to compression of neurovascular structures in the region of the thoracic outlet. CRs are divided into 2 classes as complete and incomplete forms. A clarifying description of the so-called complete CR form has not been found with sufficient information in the literature. We aimed to present a novel case of an anomalous, supernumerary, extra, or additional rib which arises from the seventh cervical vertebra. We present the case of a 23-year-old female who presented with a mass described as slowgrowing since her childhood in the supraclavicular region. The patient complained of pain, numbness, weakness, and difficulty in lifting her right arm, which increased gradually over in the last 6 months. Physical examination revealed findings of thoracic outlet syndrome (TOS). Radiographic analysis demonstrated a huge cervical rib, which resembles the size of a real thoracic rib. The cervical rib was completely resected through the supraclavicular approach. There is not enough data in theliterature about different morphologic properties of CRs. It is presented with 3-D CT images before and after surgical resection. The final version of the transformation of C7 transverse process to an original Thoracic Rib is shown. As a result, the following question presented, can it be called a Zeroth Rib?.
\end{abstract}

KEY WORDS: Anatomy; Cervical Rib Malformations; Classification; Thoracic outlet syndrome; Terminology.

\section{INTRODUCTION}

The cervical rib (CR) is a skeletal anomaly that arises from the seventh cervical vertebra and is rarely seen in the community. Radiograph images indicate that the prevalence of cervical ribs is below $1 \%$ in Turkish population; however, studies have found its occurrence to vary significantly from $0.58 \%$ to $6.2 \%$ depending on different population (Erken et al., 2002; Spadlinski et al., 2016; Henry et al., 2018). The prevalence of the CR has found to be $3 \%$ in anatolian population (Turkey) (Gulekon et al., 1999). In this single study from our country, the higher occurrence was demonstrated in women $(2.17 \%)$ than men $(0.83 \%)$. Incomplete CRs were found in $2.24 \%$ of cases. The incidence of complete CRs was found in $0.76 \%$ of cases. However, a clarifying description of the so-called complete $\mathrm{CR}$ form has not been found in the literature. It is rarely associated with thoracic outlet syndrome (TOS), although it usually has an asymptomatic course, which is usually incidentally detected on routine chest radiographs (Makhoul
\& Machleder, 1992; Davidovic et al., 2003). But on the contrary, in many patients, isolated rib anomalies can be easily missed on standard chest radiographs (Aignatoaei et al., 2018). Surgical intervention is not needed since it often has an asymptomatic course (Davies et al., 1991). It has a variable length that can be longer than $1 \mathrm{~cm}$ and can extend up to the thoracic outlet (Guttentag \& Salwen, 1999).

There is a wide spectrum of morphologic variants of rib abnormalities and unfortunately, in most instances, the boundary between malformation and anatomical variation remains unclear (Erken et al.; Spadlinski et al.; Aignatoaei et al.). In the presence of CR and the increase in the size of the cervical rib, the boundaries of the inter scalene triangle can be further constricted and result in neurovascular compression and TOS (Henry et al.). Some cases can often have arterial symptoms, albeit the reported high frequency of neurogenic symptoms (Spadlinski et al.; Henry et al.). 
Isolated rib malformations are considered by some authors "normal variants" and mainly include supernumerary ribs (cervical, lumbar), bifid ribs, rib synostosis and aplasia of the ribs (Henry et al.). Cervical ribs may also present as a mimic palpable mass in the supraclavicular fossa or may be presented as pulsation due to the displacement of the subclavian artery (Spadlinski et al.).

The CR was first described and classified into four subgroups by Gruber in 1869 (Adson \& Coffey, 1927; Abdel Ghany et al., 2017). In the 1st type, there is the only extension in the transverse process. In the 2nd type, the transverse protrusion is quite long enough to touch the 1 st rib. In the 3rd type, there is a CR, which is independent of the transverse process, but articulated with it, where the tip of the cervical rib is connected to the 1 st rib with fibrous cartilage. The fourth type is quite rare, where is a complete CR that fuses fully to the lateral superior of the first rib (Povlsen et al., 2014). Some authors have further simplified this classification by defining the terms "partial CR" and "complete CR" (Vemuri et al., 2017). The complete CRs are actually type 4. Cervical rib is also known as "Eve's rib" (Jeung et al., 1999).

The case described in this study is a very good example of complete type $4 \mathrm{CR}$. However, the anatomical appearance of a real rib attached to the cervical vertebra has produced a need for a more definitive definition. The literature review did not reveal a similar case presented with 3D images.

\section{CASE REPORT}

A 23-year-old female patient presented with a mass described as slowly growing since her childhood in the supraclavicular region on the right side of the neck. She complained of pain, numbness, weakness, and difficulty in lifting his right arm, which has increased gradually over in the last 6 months. Physical examination revealed findings of thoracic outlet syndrome. X-ray and CT examinations showed a large cervical rib in the size of a real thoracic rib, which articulated with the transverse process of the 7th cervical vertebra, originated from the vertebral body and formed a true arc and fused to the first rib. The patient's clinical complaints have increased steadily over the past 2 years. The patient reported complaints of difficulty and weakness in lifting the arm beginning from the employment status. The electrophysiological study of the brachial plexus did not reveal any positive findings. However, the Adson test showed a weakening of radial pulse even in arm abduction. An incision of 3 to $4 \mathrm{~cm}$ was made in the closest position of the CR to the skin (supraclavicular approach) and the cervical rib was first dissected tracing up to the junction with 7th cervical vertebra and resected. Then, it was carefully cut and separated using a high-speed drill from the first rib, where it had extended downward to and fused (Fig. 1). The complaints of the patient were completely resolved after surgery. Pre-operative and post-operative X-ray and 3D-CT images are shown in Figure 2.
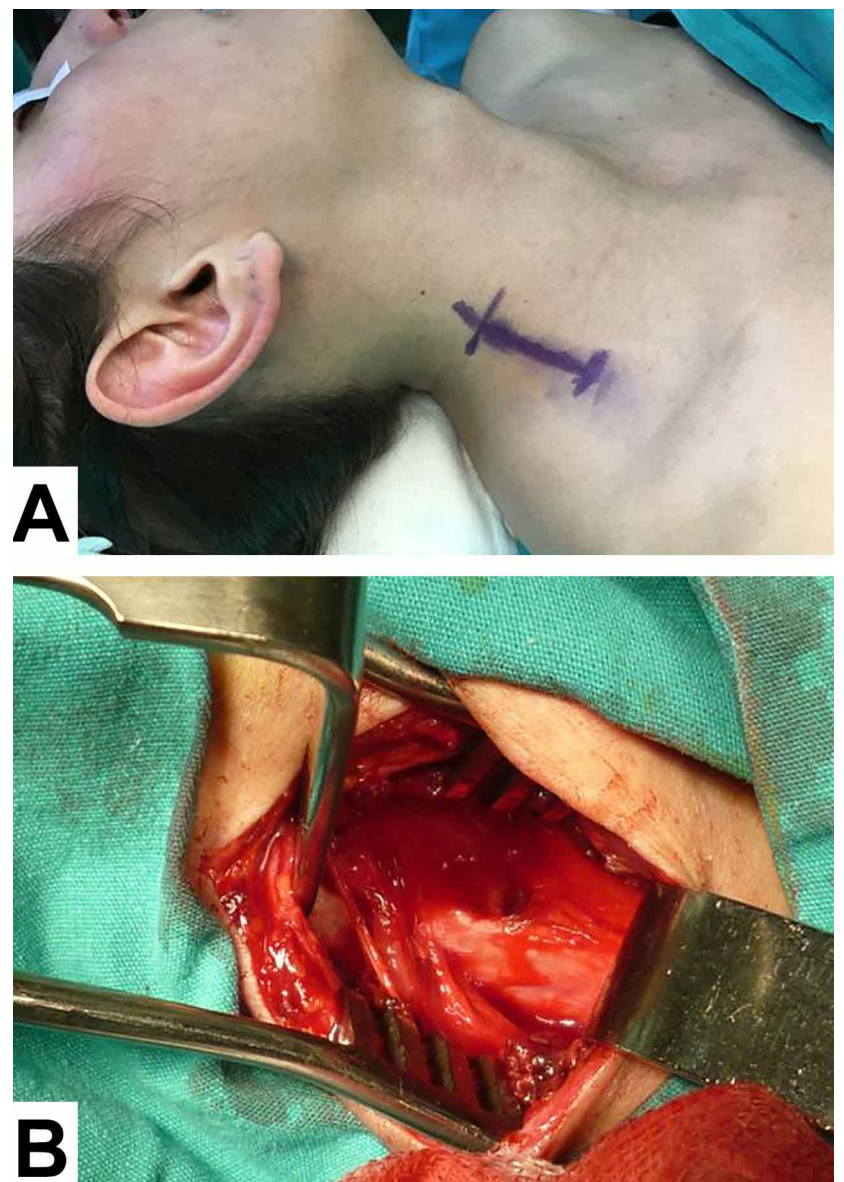

Fig. 1. A. Surgical position for supra-clavicular approach. B. Aspect to cervical rib surface during dissection.

\section{DISCUSSION}

The CR is believed to be originated from an embryonic developmental defect. At the end of the fourth week of embryogenesis, the cells of the sclerotome convert intomesenchymal cells and then into ribs. Hox genes are responsible for patterning of the axial skeleton, and mutations within them probably are implicated in the development of cervical ribs (Deschamps \& van Nes, 2005; Mallo et al., 2009; Bots et al., 2011). It has been hypothesized that abnormality in the expression of Hox genes could influence 

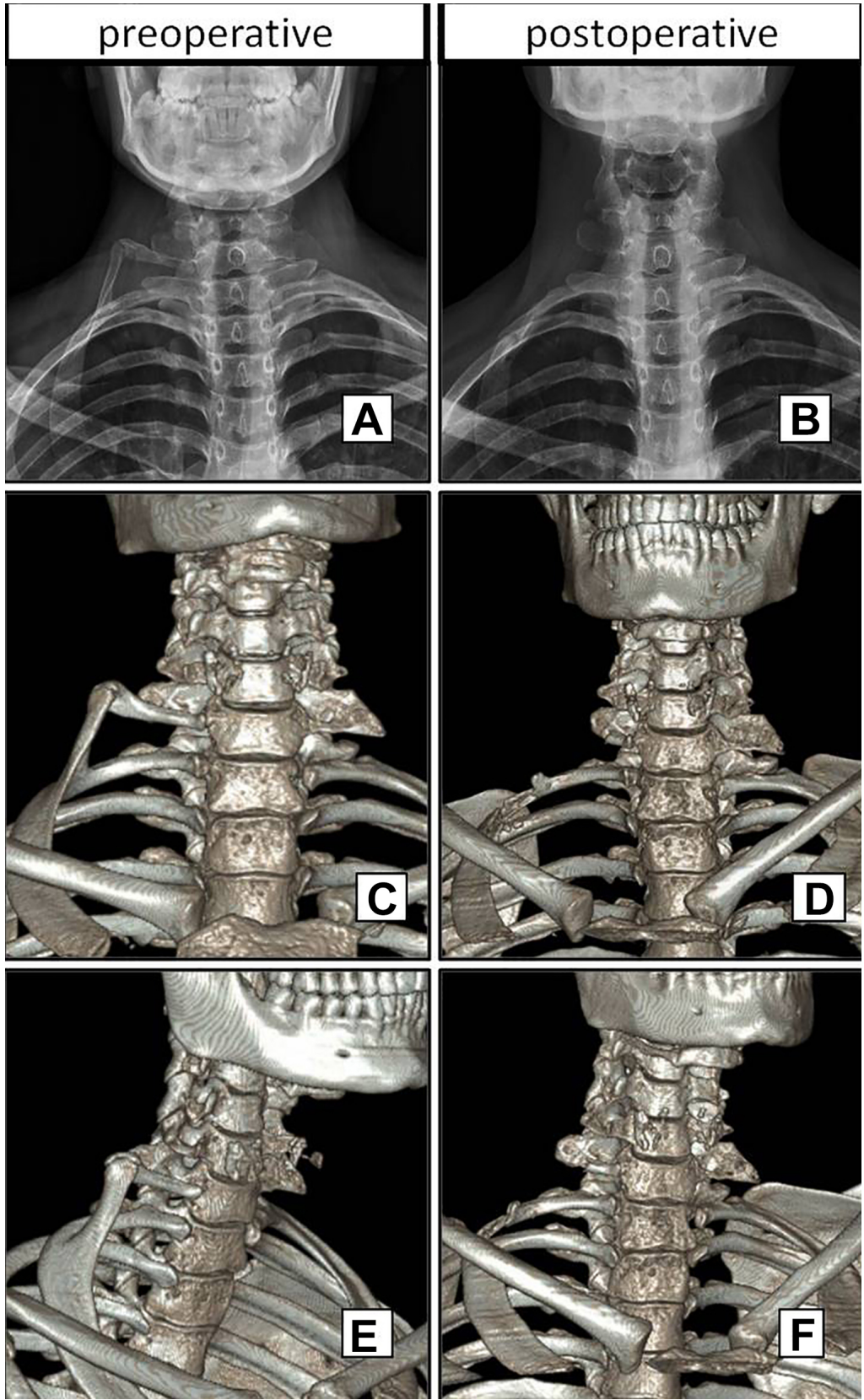

Fig. 2. A and B. Antero-posterior X-ray images. C, D, E, F. Three-Dimensional (3D) Computed tomography images. Expansion of thoracic outlet is observed after resection of the great cervical rib on $\mathrm{d}$ and $\mathrm{f}$ section. It is also observed that the whole of the cervical rib is the bone like a real rib.

oncogenesis with previous studies. Children with Germ cell tumors and astrocytoma were diagnosed with a higher rate of such cervical anomalies as cervical ribs (Merks et al., 2005). Another gene responsible for skeletal formation and growth is growth differentiation factor 11 (GDF11) (Li et al., 2010). Destruction of GDF11 function causes abnormal patterning of the anterior/posterior axial skeleton ( $\mathrm{Li}$ et al.). Although GDF11 propeptide was shown to inhibit GDF11 activity in vitro, its effect on GDF11 function in in vivo models has not been reported (Li et al.). Especially with this work in considered that transgenic overexpression of GDF11 propeptide under the control of a1 type 1 collagen promoter resulted in the transformation of $\mathrm{C} 7$ to a thoracic vertebra ( $\mathrm{Li}$ et al.). In this study, we wanted to emphasize where the transformation can last.

The presence of cervical ribs is usually asymptomatic ( $90 \%$ of patients) and does not need to their removal (Spadlinski et al.). In addition, the emergence of neurological and vascular clinical manifestations is not always related to the size of the cervical rib. The anatomical size and position must be well understood in order to better understand the underlying cause or manifestation of clinical findings. CRs are usually reported to cause only unilateral complaints, albeit reported bilaterally in almost all cases (Adson \& Coffey; Ferrante, 2012; Povlsen et al.; Vemuri et $a l$.). The presented case had complaints only in his right arm, who had type 1 cervical rib on the left side (Fig. 2).

In the normal anatomy, the subclavian artery and brachial plexus travel through space between the anterior and medial scalene muscles toward the arm. This narrow space is further narrowed by the inclusion of a CR. The subclavian artery and brachial plexus are subjected to further compression in the thoracic outlet, mainly due to the convergence of the clavicle to this area, secondary to the abduction of the arm (Abdel Ghany et al.). Clinical manifestations occur at a young age in patients with this type of CR. Elevation and upward pressure of the brachial plexus and pressure on the subclavian artery lead to neurological and vascular symptoms, respectively, or both. Or they can only be presented with a growing mass in the neck region (Buyukkaya et al., 2015). There can be the pain in the forearm and hand, paresthesia, loss of strength in the muscles of the region, and difficulty in finger movements (Adson \& Coffey; Ferrante; Chang et al., 2013; ChweiChin Chuang et al., 2016). Pain and numbness is more common in the ulnar nerve region of the hand. Neurological 
complaints may be resolved by changing the position of the arm. In the present case, there were both neurological findings and arterial findings where there is a reduction in radial pulse with positional changes.

Many authors have reported that follow-up is sufficient for asymptomatic cases. However, it has been reported that surgical treatment is the most appropriate treatment method for a CR causing such severe clinical complaints (Ferrante; Chang et al.). The most frequently used method for decompression of the thoracic outlet caused by a CR is its resection (Henry et al.). The literature reports two resection methods for cervical ribs. The first is the transaxillary approach and the second is the supra-clavicular approach.

Many authors have come to the consensus on the greater difficulty of the trans-axillary approach, which is particularly preferred for the resection of the brachial plexus and decompression of the more inferior parts of the first rib. However, there is a much higher probability of injury to the brachial plexus and vessels (Chang et al.; Henry et $a l$.). Although the supra-clavicular approach is an easier method, there are some drawbacks, including the lack of adequate vision for the complete exploration and repair of vessels in any large vessel injury (Chang et al.). However, it is a less invasive approach. This method has been reported to be more frequently saved for cases with more pronounced compression in the superior parts of the brachial plexus, with greater culpability of the compression of the anterior scalene muscle, or with or without vascular compression (Abdel Ghany et al.). In the present case, this method was preferred for the resection of the cervical rib due to the convenient palpation of lateral or distal parts of the aberrant rib, through the skin and supraclavicular area. The cervical rib was used as a landmark during surgical dissection. The body of the cervical rib was dissected tracing a route towards the vertebral body in the proximal part and the first rib in the distal part. This approach is also considered a safer approach for subclavian artery and brachial plexus as the surgical field is limited initially in the superior and later in the posterior region, in general, of these important structures (Spadlin'ski et al.; Yi et al., 2017).

The most important fact remains, as to what is the clinical effectiveness of different morphometric CR? The relationship between TOS and morphometry of the CR has not been emphasized in previous publications (Henry et $a l$.$) . For this reason, there is no similarity of this article$ due to the morphometric contribution and, this case for a morphometric property of $\mathrm{CR}$ is a good visual example as the transformation of the seventh cervical vertebrae into a thoracic vertebrae (Li et al.).

\section{CONCLUSION}

In fact, since ribs are anatomic elements that are only connected to the thoracic vertebrae, there is no use of the prefix "thoracic" before of their names. In the light of the previous information in the literature, we concluded that it would be inaccurate to make an anatomical nomenclature only with the prefix "cervical" and that there is need for a separate nomenclature, for complete ribs connected to the cervical vertebra as in the present case. Therefore, we have named this type of real rib, attached to the $\mathrm{C7}$, as the "zeroth rib", which would make a clearer distinction than other cervical ribs because this type CR is the final version in the transformation of $\mathrm{C} 7$ to a thoracic vertebrae.

KÖKSAL, V. Costilla cervical que se asemeja a una costilla torácica presentándose con síndrome de salida torácica (SST): Revisión de la literatura a partir de un caso clínico. Int. J. Morphol., 37(4):1522-1526, 2019.

RESUMEN: La costilla cervical (CC) es una anomalía esquelética rara, que generalmente se articula con el proceso transverso de la séptima vértebra cervical y generalmente conduce a la compresión de estructuras neurovasculares en la región de salida torácica. Las CC se dividen en 2 clases, como formas completas e incompletas. No se ha encontrado una descripción aclaratoria de la forma completa de CC, con información insuficiente en la literatura. El objetivo de este trabajo fue presentar un nuevo caso de costilla anómala, supernumeraria, extra o adicional que surge de la séptima vértebra cervical. Exponemos el caso de una mujer de 23 años que presentó una masa descrita como de crecimiento lento desde su infancia en la región supraclavicular. La paciente relató dolor, entumecimiento, debilidad y dificultad para levantar el miembro superior derecho, con un aumento gradual de sus síntomas en los últimos 6 meses. El examen físico reveló hallazgos del síndrome de salida torácica (SST). El análisis radiográfico demostró una costilla cervical de tamaño importante, que se asemejaba al tamaño de una costilla torácica real. La costilla cervical fue resecada completamente a través de un abordaje supraclavicular. No hay suficientes datos en la literatura sobre las diferentes características morfológicas de las CC. Se presentan imágenes tridimensionales de tomogracía computarizada, antes y después de la resección quirúrgica. Se muestra la versión final de la transformación del proceso transverso de $\mathrm{C} 7$ a una costilla torácica original. Como resultado, se plantea la siguiente pregunta, ¿se puede denominar a esta costilla como "costilla cero"?

PALABRAS CLAVE: Anatomía; Malformaciones; Costilla cervical; Clasificación; Síndrome de la salida torácica; Terminología. 


\section{REFERENCES}

Abdel Ghany, W.; Nada, M. A.; Toubar, A. F.; Desoky, A. E.; Ibrahim, H.; Nassef, M. A. \& Mahran, M. G. Modified interscalene approach for resection of symptomatic cervical rib: Anatomic review and clinical study. World Neurosurg., 98:124-31, 2017.

Adson, A. W. \& Coffey, J. R. Cervical rib: A method of anterior approach for relief of symptoms by division of the scalenus anticus. Ann. Surg., 85(6):839-57, 1927.

Aignatoaei, A. M.; Moldoveanu, C. E.; Caruntu, I. D.; Giuca, S. E.; Partene Vicoleanu, S. \& Nedelcu, A. H. Incidental imaging findings of congenital rib abnormalities - a case series and review of developmental concepts. Folia Morphol. (Warsz.), 77(2):386-92, 2018.

Bots, J.; Wijnaendts, L. C.; Delen, S.; Van Dongen, S.; Heikinheimo, K. \& Galis, F. Analysis of cervical ribs in a series of human fetuses. $J$. Anat., 219(3):403-9, 2011.

Buyukkaya, A.; Buyukkaya, R.; Ozel, M. A. \& Erdogmus, B. Cervical rib mimicking supraclavicular mass. Joint Bone Spine, 82(6):464, 2015.

Chang, K. Z.; Likes, K.; Davis, K.; Demos, J. \& Freischlag, J. A. The significance of cervical ribs in thoracic outlet syndrome. J. Vasc. Surg., 57(3):771-5, 2013.

Chwei-Chin Chuang, D.; Fang, F.; Nai-Jen Chang, T. \& Chuieng-Yi Lu, J. Thoracic outlet syndrome: Past and present- 88 surgeries in 30 years at chang Gung. Plast. Reconstr. Surg. Glob. Open, 4(6):e728, 2016.

Davidovic, L. B.; Kostic, D. M.; Jakovljevic, N. S.; Kuzmanovic, I. L. \& Simic, T. M. Vascular thoracic outlet syndrome. World J. Surg., 27(5):545-50, 2003.

Davies, A. H.; Walton, J.; Stuart, E. \& Morris, P. J. Surgical management of the thoracic outlet compression syndrome. Br. J. Surg., 78(10):1193-5, 1991.

Deschamps, J. \& van Nes, J. Developmental regulation of the Hox genes during axial morphogenesis in the mouse. Development, 132(13):2931-42, 2005.

Erken, E.; Ozer, H. T.; Gulek, B. \& Durgun, B. The association between cervical rib and sacralization. Spine, 27(15):1659-64, 2002.

Ferrante, M. A. The thoracic outlet syndromes. Muscle Nerve, 45(6):78095, 2012.

Gulekon, I. N.; Barut, C. \& Turgut, H. B. The prevalance of cervical rib in Anatolian population. Gazi Med. J., 10:149-52, 1999.

Guttentag, A. R. \& Salwen, J. K. Keep your eyes on the ribs: the spectrum of normal variants and diseases that involve the ribs. Radiographics, 19(5):1125-42, 1999.

Henry, B. M.; Vikse, J.; Sanna, B.; Taterra, D.; Gomulska, M.; Pekala, P. A.; Tubbs, R. S. \& Tomaszewski, K. A. Cervical rib prevalence and its association with thoracic outlet syndrome: A meta-analysis of 141 studies with surgical considerations. World Neurosurg., 110:e96578,2018

Jeung, M. Y.; Gangi. A.; Gasser, B.; Vasilescu, C.; Massard, G.; Wihlm, J. M. \& Roy, C. Imaging of chest wall disorders. Radiographics, 19(3):617-37, 1999.

Li, Z.; Kawasumi, M.; Zhao, B.; Moisyadi, S. \& Yang, J. Transgenic over-expression of growth differentiation factor 11 propeptide in skeleton results in transformation of the seventh cervical vertebra into a thoracic vertebra. Mol. Reprod. Dev., 77(11):990-7, 2010.

Makhoul, R. G. \& Machleder, H. I. Developmental anomalies at the thoracic outlet: an analysis of 200 consecutive cases. J. Vasc. Surg., 16(4):534-42, 1992.

Mallo, M.; Vinagre, T. \& Carapuço, M. The road to the vertebral formula. Int. J. Dev. Biol., 53(8-10):1469-81, 2009.

Merks, J. H.; Smets, A. M.; Van Rijn, R. R.; Kobes, J.; Caron, H. N.; Maas, M. \& Hennekam, R. C. Prevalence of rib anomalies in normal Caucasian children and childhood cancer patients. Eur. J. Med. Genet., 48(2):11329, 2005.
Povlsen, B.; Hansson, T. \& Povlsen, S. D. Treatment for thoracic outlet syndrome. Cochrane Database Syst. Rev., (11):CD007218, 2014.

Spadlinski; Cecot, T.; Majos, A.; Stefanczyk, L.; Pietruszewska, W.; Wysiadecki, G.; Topol, M. \& Polguj, M. The epidemiological, morphological, and clinical aspects of the cervical ribs in humans. Biomed. Res. Int., 2016:8034613, 2016.

Vemuri, C.; McLaughlin, L. N.; Abuirqeba, A. A. \& Thompson, R. W. Clinical presentation and management of arterial thoracic outlet syndrome. J. Vasc. Surg., 65(5):1429-39, 2017.

Yi, J. A.; Johnston, R. J.; Nehler, M. R.; Gibula, D. R.; Alix, K.; Glebova, N. O. \& Brantigan, C. O. A fourteen-year experience with vascular anomalies encountered during transaxillary rib resection for thoracic outlet syndrome. Ann. Vasc. Surg., 40:105-11, 2017.

Corresponding author:

Vaner Köksal

Department of Neurosurgery

University of Health Sciences-Samsun Health Practices and

Research Center

Samsun

TURKEY

Email: vanerkoksal@hotmail.com

Received: 03-03-2019

Accepted: 17-06-2019 